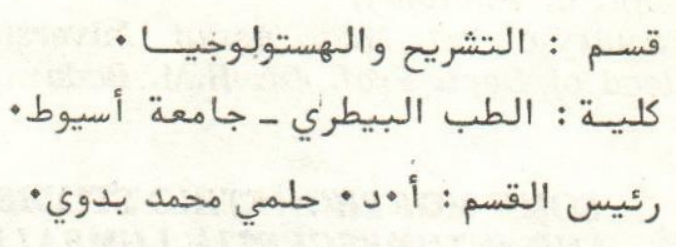

بعض الدراسات المورفولوجية والقياسية على التضخم العنقي والتفضم القطني للسر أغ واليط والعطام

حلمي بدوي ، عبدالهادي محمد ، محمد المحرزي ، ط• ب• ايمان حسونه

أجري البحث على خمسة عشر طائر بالغ من كل من الفراخ الفيومي والبط البكينـي

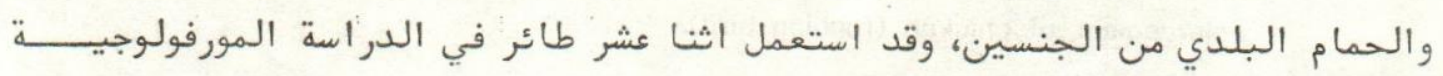
وثلاثة طيور للدراسات القياسية الجندين

اثبتت الدراسات التي أجريت أن التضخم العنقي في الحمام والتضخم العجزي

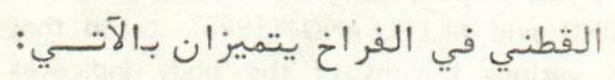

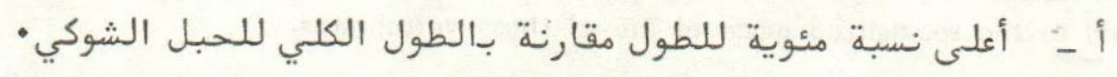

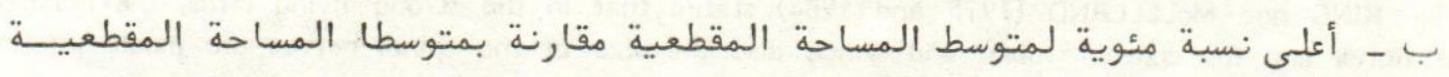

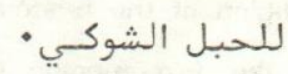
جـ - أعلى نسبة مئوية للحجم مقارنة للحجم الكلي للحبل الشوكي.

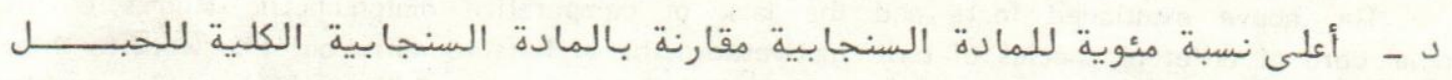
الشــــــي الشي 
Dept. of Anatomy,

Faculty of Vet. Med., Assiut University,

Head of Dept. Prof. Dr. H.M. Badawi.

\title{
SOME MORPHOMETRIC STUDIES ON INTUMESCENTIA CERVICALIS AND INTUMESCENTIA LUMBALIS OF FOWL (GALLUS DOMESTICUS), DUCK (ANAS DOMESTICA) AND PIGEON (COLUMBIA LIVIA) (With 2 Tables \& 2 Figs.)
}

By

\author{
H.M. BADAWI; A.M. ALI; M.M. ABDEL-MONEIM and E.M. HASOUNA \\ (Received at 10/10/1987)
}

\section{SUMMARY}

Dimensional differences between the cervical and lumbosacral enlargements in the three examined birds revealed that the highest percentage of length, volume and GM. volume and the largest ratio of mean of C.S.A. to the mean C.S.A. of the whole cord was observed in cervical enlargement of pigeon (flying bird) and in lumbosacral enlargement of chicken (running bird).

\section{INTRODUCTION}

The intimate relationship between the muscular and nervous system is an interesting subject for many morphologists. ARIENS KAPPERS, HUBER and CROSBY (1965), SCHUMMER (1977) and KING and MCLELLAND (1984) stated that the quantitative distribution of the skeletal musculature in various regions of the body indicates adaptation to the overall structure of the avian bor? and to the specialized mode of life of these vertebrates.

KING and MCLELLAND (1975 and 1984) stated that in the strong flying birds, the number of fibres and the size of roots, and hence also the size of the spinal nerves are much greater in the region of the brachial plexus than elsewhere.

In the fast running birds like the ostrich, the roots of spinal nerves are greatly enlatged in the region of the lumbosacral plexus.

The above mentioned facts and the lack of comparative morphometric studies on the spinal cord of different species of birds motivetated the authors to carry out this work to throw lights on the diferent morphological features of the spinal cord of three bird species adapted with different types of muscular movement including running in chickens, swimming and diving in ducks and flying in pigeons.

\section{MATERIAL and METHODS}

This work was carried out on adult healthy chickens, ducks and pigeons of both sexes. Twelve birds from each species were used for morphological studies and three for morphomet-ic studies. The birds were anaesthetized with chloroform inhalation, bleed through the common carotid artery and fixed with 10\% formalin. The vertebral column was cleaned from the surrounding soft tissues. The above fixed specimens were decalcified and complete laminoctomy was 


\section{H.M. BADAWL, et al.}

carried out. The lenghth (DVD and T.D) of the different spinal segments were measured. The surface area of five sections from each spinal cord segment as well as the surface area of its gray matter were determined by the method of planimetry by counting points adopted by WELBEL and ELLAS (1967).

The segment volume is calculated by multiplying the cross sectional areas by the segment length. The nomenclature used in this work is adopted by Nomina Anatomica Veterinaria (1983).

\section{List of Abbreviations}

$\begin{array}{ll}\text { Bet. } & \text { between. } \\ \text { Ca. } & \text { Caudal. } \\ \text { C. } & \text { cervical } \\ \text { C.E. } & \text { Cervical enlargement. } \\ \text { C.S.A. } & \text { Cross-Sectional area. } \\ \text { D.V.D. } & \text { Dorsoventral diameter. } \\ \text { GL.B. } & \text { glycogen body. }\end{array}$

GM. Gray matter.

Ls. Lumbosacral.

Ls.E. Lumbosacral enlargement.

Rh.Si. Rhomboid sinus.

T.D. Transverse diameter.

T. Thoracic.

WM. White matter.

\section{RESULTS}

The spinal cord of the three examined birds form the narrow elongated part of the central nervous system which filled the whole length of the vertebral canal. It appeared more or less cylindrical in form and decreased in diameter caudally.

Along the whoie length of the cord there were two enlargements from which arose the plexuses of the limbs. The cranial one is the cervical enlargement, (Intumescentia cervicalis), corresponding to the origin of the wings, was situated at the border between the cervical and thoracic regions. The caudal one is the lumbosacral enlargement, (Intumescentia lumbalis), corresponding to the position of the pelvic limb.

\section{Intumescentia cervicalis:}

Table (1) and Fig. (1, 2) showed that the cervical enlargement extended from the last two cervical to the first two thoracic segments in chickens and ducks and in case of pigeons from the last three cervical to the first two thoracic segments.

The percentage of the cervical enlargement length to the whole length of the cord varied in the three examined birds, it formed $10.53 \%$ in chickens $8.5 \%$ in ducks and $15.33 \%$ in pigeons.

The ratio between the mean of the C.S.A. of the segments forming the C.E. to that of the whole cord was found to be similar in chickens and ducks ( $1: 1.4)$ while in pigeons, it was $1: 1.5$.

The percentage of the volume of the cervical enlargement to that of the whole cord varied greatly in the three species. The lowest percentagte was in ducks 13.9\% and the highest one was in pigeons $23.05 \%$ while in chickens it was $15.83 \%$. The differences between the values obtained in the three birds was statistically significant.

The percentage of volume of the GM. of C.E to the whole GM. of the cord was nearly similar in chickens and ducks $(21.61 \%$ and $21.11 \%)$ while in the pigeons it was found to be significantly higher and reached $27.8 \%$. 


\section{INTUMESCENTIA CERVICALIS AND LUMBALIS}

\section{Intumescentia lumbalis:}

The present investigation showed that the lumbosacral enlargement in chickens extended from the last thoracic segment to the eighth lumboscaral one while in ducks and pigeons it extended from the first to the eighth lumbosacral segments (Table 2). The length of the lumbosacral enlargement formed $12.29 \%, 8.13 \%$ and $8.93 \%$ of the whole length of the cord in chickens, ducks and pigeons respectively.

The ratio between the mean of C.S.A. of the segments entered in the formation of the lumbosacral enlargement to that of the cord was $1: 2$ in chickens, $1: 1.77$ in ducks and 1:1.59 in pigeons.

The volume of lumbosacral enlargement in chickens formed $25.36 \%$ from the total volume of the cord while in ducks and pigeons this values were much lower and reached $10.24 \%$ and $14.51 \%$, respectively. However, the volume of GM. in the segments forming the Ls.E. to the whole volume of GM. of the cord was found to be signiticantly high in chicken and formed 34.66\%. In ducks and pigeons this percentage was relatively low and was found to be 21.56 and 19.68 respectively.

In the three examined birds the Rh. Si. extended from ( $\left.\mathrm{Ls}_{2}-\mathrm{Ls}_{3}\right)$ to $\mathrm{Ls}_{7}$. However, its length varied in the three species and reached $24 \mathrm{~mm}, 23.3 \mathrm{~mm}$ and $14.1 \mathrm{~mm}$ in chickens, ducks and pigeons, respectively. It formed $37.01 \% 30.57 \%$, 33.61\% from the total length of the lumbosacral enlargement in the examined birds, respetively.

The glycogen body extended from $\mathrm{Ls}_{3}$ to $\mathrm{Ls}_{6}$ in the three examined birds. The percentage of the length of the glycogen body to that of the lumbosacral enlargement ranged from $30-37$. The glycogen body was found to be relatively more developed in chickens and ducks where its volume reached $2.68 \%$, and $1.96 \%$ of the total volume of the cord, respectively. However in pigeons the glycogen, body was less developed and formed $1.58 \%$ of the total volume of the cord.

\section{DISCUSSION}

The present investigation revealed that the cervical enlargment in chicken extended form the fourteenth cervical segment to the second thoracic one. WATTERSON (1949), YASUDA (1960), KING and MCLELLAND (1975, 1984) and BUMEL (1975) found that the cervical enlargment in chicken extends from the thirteenth cervical to the first thoracic segment and even to the second one BRADLEY (1960).

In ducks the present work showed that the cervical enlargment extended from $\mathrm{C}_{15}$ to $T_{2}$, while, SCHUMMER (1977) stated that it extended from $\mathrm{C}_{14}$ to $\mathrm{T}_{2}$.

In accordance with the present study, HUBER (1936) found that the cervical enlargment extend from $C_{11}$ to $T_{2}$ in pigeons.

The ratio between the D.V.D. and the T.D., in the three examined birds, was more or less the same in all the regions of the cord encluding the cervical and lumbosacral enlargements. However, this ratio was found to be relatively high at the cervical enlargment of pigeons where it reached up to $(1: 1.9)$ and its volume formed nearly $23 \%$ of the whole volume of the cord. KING and MCLELAND (1984) stated that in the strong flying birds the number of fibres and 


\section{H.M. BADAWI, et al.}

the size of roots and hence also the size of spinal nerves are much greater in the region of the cervical enlargement than elsewhere.

Although the ratio between the D.V.D. and the T.D. of the segments entering in the formation of Ls.E. was found to be nearly similar in the three studied birds, statistical analyses showed that the total volume of the different segments entering in the formation of the Ls.E. of chichens was significantly high when compared with that of the ducks and pigeons BAUMEL (1975) mentioned that the average of the D.V.D. at the Ls.E. in chickens was about 7 mm.; V.d. AKKER (1970) in pigeons, found that the diameter of the cord at the intumescentia lumbosacralis was $4 \mathrm{~mm}$.

STREETER (1904) stated that the lumbosacral enlargement in ostrich was greater than the cervical one where the musculature of the hind extremities are well developed and consequentlly the cord at this enlargement had a large transverse diameter.

Statistical analysis also confirmed the fact that the cervical enlargement was more developed in flying than in running and swimming birds where the cervical enlargment in pigeons formed $23.05 \%$ of the total volume of the cord. This percentage is greatly reduced in ducks and chickens where it reached 13.84 and 15.83 , respectively.

Also the percentage of GM. in the cervical enlargment compared to the whole volume of the GM. of the spinal cord was significantly higher in pigeons than in ducks and chickens.

These diferences were also recorded at the lumbosacral enlargement, where it was found to be significantly greater in chickens (running bird) than in ducks and pigeons, and the percentage of its volume to the whole volume of the cord reached 25-36 where it ranged between 14 and 16 in the other two species. This increase in the total volume of the Ls.E. was also accompanied by an increase in the volume of its GM. where it formed 34-66\% of the whole volume of the cord.

\section{REFERENCES}

Akker, V.D. L.M. (1970): An Anatomical outline of the spinal cord of the pigeon. Van Gorcum \& Comp. N.V.D.R.H.J. Prakke \& H.M.G. Prakke Assen.

Baumel, J.J. (1975): Aves nervous system, centeral nervous system in Sisson and Grossman. The anatomy of the domestic animals. Rev. by R. Getty, 5th ed. W.B. Saunders Co., Philad., London, Toronto.

Bradley, O.C. and T. Grahame (1959): Topographical anatomy of the dog. 6th Ed. Macmillan Comp., New York.

Huber, J.F. (1936): Nerve roots and nuclear groups in the spinal cord of the pigeon. Jour. Comp. Neurol. 65, 43-91.

Kappers, A.C.U.; G.C. Huber and E.C. Crosby (1965): The comparative anatomy of the nervous system of vertebrates including man. Vol. 1. Hafner Publ. Co., New York.

King, A.S. and J. McLelland (1975): Qutlines of Avian Anatomy, 1st Ed. Bailliere Tindall, London.

King, A.S. and J. McLelland (1984): Birds, their Structure and Function 2nd Ed. Bailliere Tindall London, Philad., Toronto.

Nomina Anatomica Veterinaria (1983): 3rd Ed. Publ. by int. committe on Vet. Gross Anat. Nomeclature. Ithaca, New York.

Schummer, A. (1977): In Nickel, Schummer and Seiferle Anatomy of the domestic Birds. Vol. 5 Nervous system. Paul Barey Berlin and Hamburg.

Assiut Vet.Med.1. 19, No. 38, 1988. 


\section{INTUMESCENTIA CERVICALIS AND LUMBALIS}

Watterson, R.L. (1949): Development of the glycogen body of the chick spinal cord. 1- Normal morphogenesis, Vasculogenesis ad anatomical relationships. Jour. Morph. 85: 337-390.

Weibel, E.R. and H. Elias (1967): Introduction to stereology and morphometry. In Quantitative Methods in Morphology. Springer, Berlin, Heidelberg and New York.

Yasuda, M. (1960): Comparative and Topographical anatomy of the fowl. III- On the nervous spply of the thoracic limb in the fowl. Jap. Jour. Vet. Sci. 22, 89-101.

Table (1)

Various dimensions of cervical enlargement

(Intumescentia cervicalis)

\begin{tabular}{llll}
\hline & Chicken & Duck & Pigeon \\
\hline & & & \\
- Extension & $C_{14}-T_{2}$ & $C_{15}-T_{2}$ & $C_{11}-T_{2}$ \\
- Length & $35 \mathrm{~mm}$ & $40.7 \mathrm{~mm}$ & $30.5 \mathrm{~mm}$ \\
Ratio bet D.V.D. and T.D. at the C.E. & $1: 1.8$ & $1: 1.7$ & $1: 1.9$ \\
- \% to the cord & $10.53 \%$ & $8.5 \%$ & $15.33 \%$ \\
- Mean of C.S.A. & $5.17 \mathrm{~mm}^{2}$ & $5.35 \mathrm{~mm}^{2}$ & $3.36 \mathrm{~mm}^{2}$ \\
- Ratio bet. C.S.A. of the cord & $1: 1.42$ & $1: 1.41$ & $1: 1.51$ \\
to C.S.A. of the C.E. & $179.21 \mathrm{~mm}^{3}$ & $210.85 \mathrm{~mm}^{3}$ & $99.68 \mathrm{~mm}^{3}$ \\
- Volume & $15.83 \%$ & $13.84 \%$ & $23.95 \%$ \\
- \% of vol. to total cord vol. & $60.18 \mathrm{~mm}^{3}$ & $73.36 \mathrm{~mm}^{3}$ & $31.29 \mathrm{~mm}^{3}$ \\
- Vol. of GM. & $21.61 \%$ & $22.11 \%$ & $27.81 \%$ \\
- \% GM. vol. total vol. of GM. & & & \\
\hline
\end{tabular}


H.M. BADAWL, et al.

Table (2)

Various diamenolons of lumbosacral entargement

(intumescentia lumbalis)

\begin{tabular}{|c|c|c|c|}
\hline & Chicken & Duck & Pigeon \\
\hline - Extention & $\mathrm{T}_{7}-\mathrm{Ls}_{8}$ & $\mathrm{Ls}_{1}-\mathrm{Ls}_{8}$ & $\mathrm{Ls}_{1}-\mathrm{Ls}_{7}$ \\
\hline - Length & $40.65 \mathrm{~mm}$ & $39.0 \mathrm{~mm}$ & $17.8 \mathrm{~mm}$ \\
\hline Ratio bet D.V.D. and T.D. at the LS.E. & $1: 1.8$ & $1: 1.7$ & $1: 1.7$ \\
\hline - \% to total cord length & $12.29 \%$ & $8.13 \%$ & $8.93 \%$ \\
\hline - Mean of C.S.A. & $7.31 \mathrm{~mm}^{2}$ & $6.39 \mathrm{~mm}^{2}$ & $3.54 \mathrm{~mm}^{2}$ \\
\hline $\begin{array}{l}\text { - Ratio bet. C.S.A. of the cord } \\
\text { to C.S.A. of LS.E. }\end{array}$ & $1: 2.0$ & $1: 1.77$ & $r: 1.59$ \\
\hline - Volume & $287.23 \mathrm{~mm}^{3}$ & $246.23 \mathrm{~mm}^{3}$ & $62.76 \mathrm{~mm}^{3}$ \\
\hline - \% of vol. to total cord volume & $25.36 \%$ & $16.24 \%$ & $14.51 \%$ \\
\hline - Vol. of GM. & $96.53 \mathrm{~mm}^{3}$ & $73.05 \mathrm{~mm}^{3}$ & $22.14 \mathrm{~mm}^{3}$ \\
\hline - \% of vol. of GM. to total GM. vol. & $34.66 \%$ & $21.56 \%$ & $19.68 \%$ \\
\hline - Volume of W.M. & $160.24 \mathrm{~mm}^{3}$ & $143.75 \mathrm{~mm}^{3}$ & $33.8 \mathrm{~mm}^{3}$ \\
\hline \% of W.M. vol. to total vol. of W.M. & $19.46 \%$ & $12.52 \%$ & $10.80 \%$ \\
\hline - Extension of Rh.Si. & $\mathrm{Ls}_{2}-7$ & $\mathrm{Ls}_{3}-7$ & $\mathrm{Ls}_{2}-7$ \\
\hline - Length of Rh.Si. & $24 \mathrm{~mm}$ & $23.3 \mathrm{~mm}$ & $14.1 \mathrm{~mm}$ \\
\hline - Extension of Gl.B. & $\mathrm{Ls}_{3}-\mathrm{Ls}_{6}$ & $16_{3}-\mathrm{Ls}_{6}$ & $\mathrm{Ls}_{3}-\mathrm{Ls}_{6}$ \\
\hline - Length of Gl.B. & $15.5 \mathrm{~mm}^{3}$ & $18.4 \mathrm{~mm}^{3}$ & $8.9 \mathrm{~mm}^{3}$ \\
\hline
\end{tabular}

Assiut Vet.Med.l. 19, No. 38, 1988. 

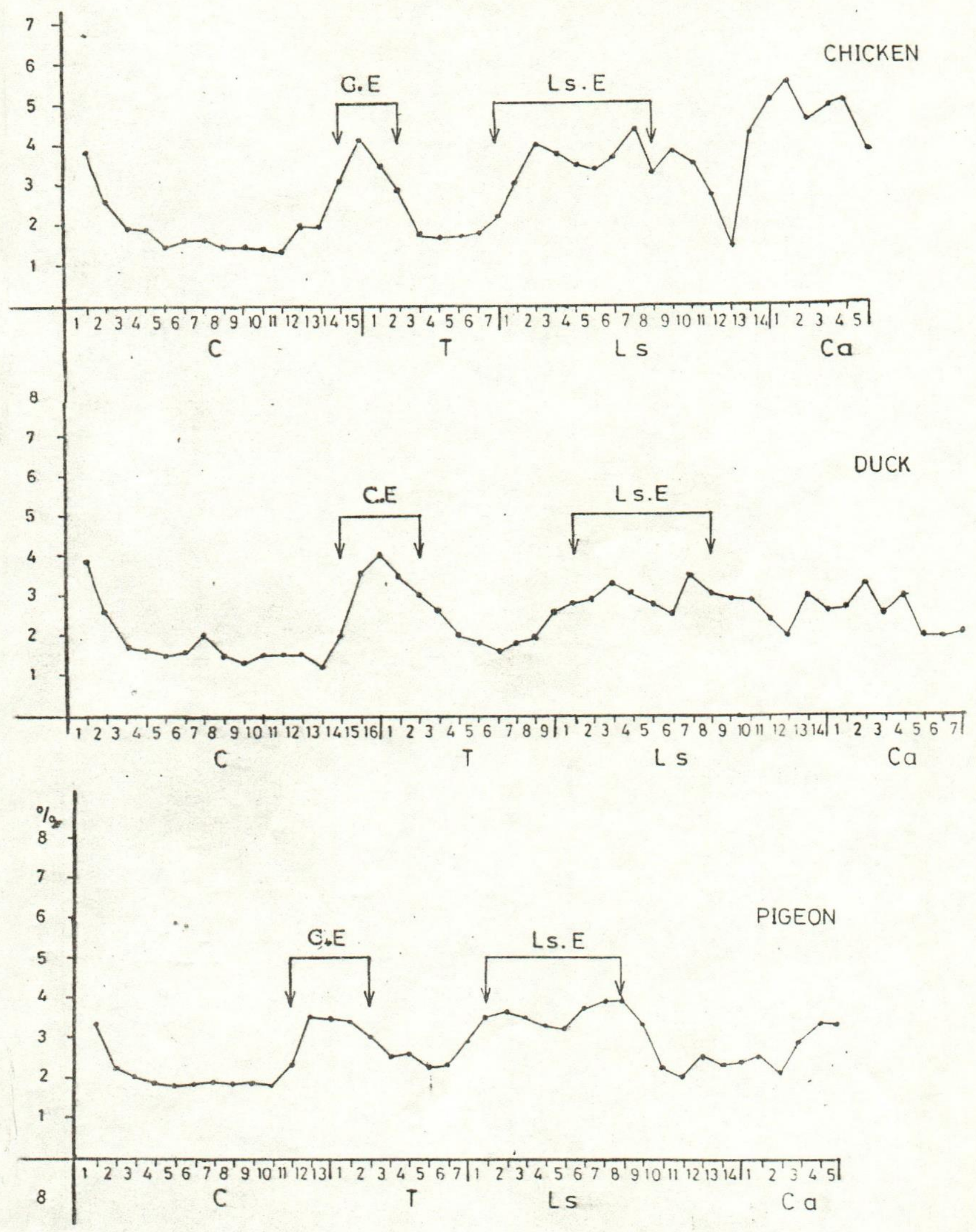

Fig (1 ) Percentage of gray matter volume in the individuol spinal cord segments of chicken duck and pigeon 


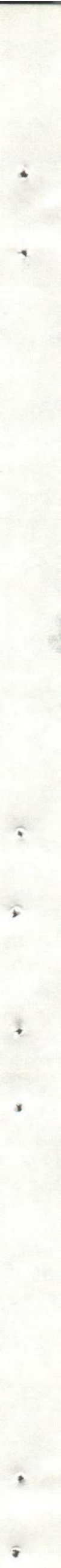




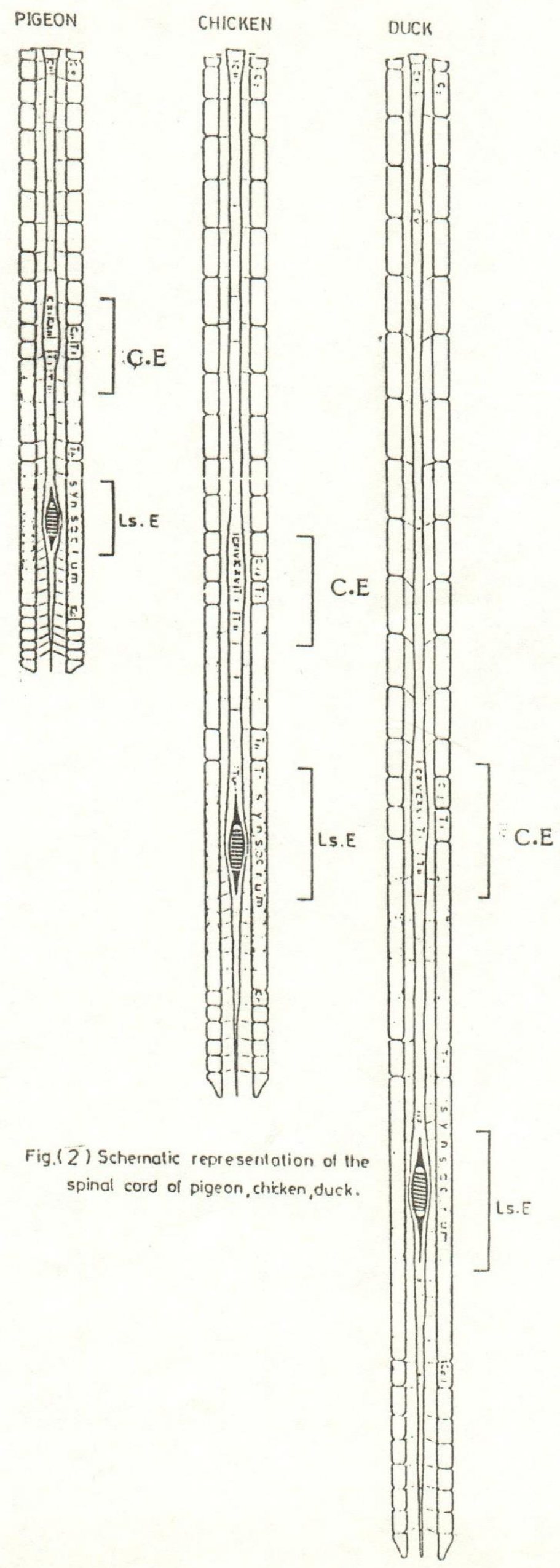


